\title{
SULFATION OF PALM SEED (Arenga pinnata Merr.) GALACTOMANNAN: ANTIMICROBIAL ACTIVITY AND TOXICITY TEST
}

\author{
J. Kaban ${ }^{1 *}$, J. Reveny ${ }^{2}$, J. Tarigan ${ }^{1}$ and N.F. Zebua ${ }^{2}$ \\ ${ }^{1}$ Department of Chemistry, University of Sumatera Utara, Medan, Indonesia \\ ${ }^{2}$ Department of Pharmacy, University of Sumatera Utara, Medan, Indonesia \\ *E-Mail: jamarankaban@yahoo.com
}

\begin{abstract}
Palm seeds galactomannan are extracted by water in sedimentation. The synthesis of sulfated galactomannan with chlorosulfonic acid (CSA) as a sulfating agent and with pyridine and dimethyl formamide as a solvent was then characterized by functional group changes with FT-IR. Antimicrobial tests were performed by agar diffusion method against Staphylococcus aureus, Escherichia coli, and Candida albicans. Acute toxicity test of sulfated galactomannan was carried out on 3 groups of animals (mice); control (palm seed galactomannan), sulfated galactomannan dose $2000 \mathrm{mg} / \mathrm{kg}$ body weight and $5000 \mathrm{mg} / \mathrm{kg}$ body weight given in a single dose and observed for 14 days.Galactomannan extraction result of palm seed yields 4,8\%. The spectral of sulfated synthesis of wave numbers $1284.59 \mathrm{~cm}^{-1}$ and $763.81 \mathrm{~cm}^{-1}$. The result of the antimicrobial test from sulfated galactomannan at 100 $\mathrm{mg} / \mathrm{ml}$ concentration yields $9-10 \mathrm{~mm}$ diameter (not minus the diameter of the metal ring) in Staphylococcus aureus and Eschericia coli whereas in Candida albicans did not show any inhibition zone so it could be categorized weak antibacterial. Acute toxicity test results in sulfated galactomannan mice group of $5000 \mathrm{mg} / \mathrm{kg} \mathrm{BW}$ dying on day 14 , so sulfated galactomannan can be categorized as mild toxicity.

Keywords: Aren Seed, Arenga pinnata, antibacterial, antifungal, sulfation, galactomannan, acut toxicity.
\end{abstract}

(c) RASĀYAN. All rights reserved

\section{INTRODUCTION}

Galactomannan is a group of polysaccharides having varying molecular weights, from 6000 to 17000 . Galactomannan has been isolated from palm seed using distilled water and the separation is done by centrifugation so as to obtain galactomannan content of $4.58 \% .^{1}$ Galactomannan has generally been widely applied and used in the food, pharmaceutical, cosmetic and paper industries. Galactomannan is a polar glycoside component. ${ }^{2}$ Polysaccharides have attracted the attention of biochemical researchers and nutritionists in recent years due to their biological activity. Many researchers have shown that the biological activity of polysaccharides can be modified by modifying its functional groups. Modified molecules and polysaccharide structures are performed to obtain better physiological properties for health and prevent disease. Sulfated polysaccharide contain sulfate groups which replace hydroxyl groups. ${ }^{3}$

Synthesis of polysaccharide sulphate has been performed by using clorosulfonic acid reagent as a sulfating agent. The solvents used in the synthesis are pyridine and dimethyl formamide because the mixture of these two solvents gives the most results ${ }^{4}$. Galactomanan sulphate from Adenthera pavonina, Caesalpinia ferrea and Dimorphandra gardneriana have antibacterial properties so that sulphonate synthesis is important to do ${ }^{5}$. Sulfated galactomannan from palm seeds has not been reported previously. Based on the above, the researcher is interested in conducting a study on the sulphated palm oil galactomannan with chlorosulfonic acid-pyridine-DMF and tested as an antimicrobial and to ensure the safety of an acute toxicity test.

\section{EXPERIMENTAL}

The study was conducted at the Organic Chemistry Laboratory, Faculty of Mathematic and Natural Science, Universitas Sumatera Utara. Plant material used in this research is the palm seed which is determined by the Herbarium Medanense of the biology department. Toxicity tests on animals have been approved by animal research ethics committees faculty of Mathematic and natural science. Materials used 
are ethanol, dimethyl formamide, pyridin, cholorosulfonic acid, sodium bicarbonate, methanol, Mueller Hinton Agar (MHA), Sabouraud Dextrose Agar (SDA), formaldehyde, and chloroform (Merck). The tools used are analytical balance (Sartorius), centrifuge (Hitachi), heating mentle (Seoh), and incubator (Memmert). Palm seed gum was characterized by Infrared Spectrophotometer (Shimadzu).

\section{Palm Seeds Galactomannan Extraction}

1000 grams of palm seeds cleaned, cut, blended with the addition of distilled water as much as $10 \mathrm{~L}$, then steamed for 5 minutes and stored in the refrigerator for 24 hours. The precipitate was separated and the supernatant added $96 \%$ ethanol of $20 \mathrm{~L}$, stored in the refrigerator for 24 hours. The formed aggregate is filtered and dehydrated with ethanol p.a. and dried in a desiccator producing white galactomannan seed powder ${ }^{1,2}$.

\section{Galactomannan Sulfation}

$200 \mathrm{mg}$ of galactomannan palm seeds added dimethyl formamide and pyridine 50/10 (v/v) distiller for 12 hours at room temperature. $4 \mathrm{ml}$ of clorosulfonic acid slowly added while distirer for 24 hours in temperature $1-4^{\circ} \mathrm{C}$. The reaction product is neutralized by the addition of sodium bicarbonate, the precipitate formed then decanted. The precipitate was washed several times with cold methanol to remove pyridine, salt and other degradation products, then were dialyzed with water for 5 days, then dried in a desiccator to produce sulfated galactomannan of colloidal palm seed ${ }^{6}$.

\section{Antimicrobial Test}

Tests of antimicrobial activity against sulfated galactomannan of palm seeds were done by a diffusion method using a metal ring, bacteria used was Staphylococcus aureus ATCC 29737 as Gram positive bacteria, Eschericia coli ATCC 10536 Gram negative bacteria, and Candida albicans ATCC 10231 as fungus. Diameter Determination of bacterial growth inhibition by measuring the diameter of the clear area around the hole using the sliding term ${ }^{7}$.

$0.1 \mathrm{~mL}$ of a bacterial suspension with a concentration of $10^{6} \mathrm{cfu} / \mathrm{mL}$ was added $20 \mathrm{~mL}$ of MHA (for bacteria) and SDA (for mushroom) test medium inserted into a sterile petri dish, then homogenized and planted in a metal ring. Wait for a while until hardened. After the solid media, placed the metal inculcation using tweezers, then each well filled with sulfated galactomannan palm seeds. Then it was incubated at a temperature of $35 \pm 2^{\circ} \mathrm{C}$ for $1 \times 24$ hours in the incubator. Clear zones around the hole are observed $^{8}$.

\section{Acute Toxicity Test}

The acute toxicity test was performed on male mice and grouped into 5 groups and each group consisted of 6 mice. Each group was given $1 \%$ water, $1 \%$ galactomannan and sulfated galactomannan with dose, respectively $1000 \mathrm{mg} / \mathrm{kg}, 2000 \mathrm{mg} / \mathrm{kg}$, and $5000 \mathrm{mg} / \mathrm{kg}$ body weight in mice. If there are test animals that die before the 24th hour after the administration of the test preparation, the mice are dissected for the liver and kidneys to be removed. Observation on the behavior of mice (toxic symptoms) was done for 14 days. Mice were weighed daily, and on the 15th day surgery was performed to look at the mouse organ macroscopically and the weight of organs. Histopathologic features were performed on liver and kidney organ of mouse ${ }^{9}$.

\section{Extraction and Sulfation Result}

\section{RESULTS AND DISCUSSION}

1000 grams of palm seeds after extracted with the heating method and sedimentation obtained white solids so that obtained results as much as 48 grams (4.8\%). Galactomannan was analyzed by FT-IR spectrophotometer (Fig.-1) produces a high-intensity stretching band at $3390,86 \mathrm{~cm}^{-1}$ indicating the presence of $-\mathrm{OH}$ groups supported by bending vibrations at $1103.28 \mathrm{~cm}^{-1}$ indicating -CO groups attached to $\mathrm{OH}$ group. Vibration stretching at $2900,94 \mathrm{~cm}^{-1}$ shows the presence of cluster $-\mathrm{CH}_{2}$ which is supported by bending vibration at $1311,59 \mathrm{~cm}^{-1}$ showing cluster $-\mathrm{CH}_{2}$. The synthesis of sulfated galactomannan was analyzed by FT-IR spectrophotometer (Fig.-2) resulting in vibration stretching at $3394.72 \mathrm{~cm}^{-1}$ indicating 
RASĀYAN J. Chem.

Vol. 11 | No. 1 | 294 - 299 | January - March | 2018

the presence of -OH group supported by bending vibration at $1103.28 \mathrm{~cm}^{-1}$ indicating the presence of C-O group attached to the -OH group. Vibration stretching at $2931,80 \mathrm{~cm}^{-1}$ shows the presence of $-\mathrm{CH}_{2}$ which is supported by bending vibration at $1408.04 \mathrm{~cm}^{-1}$ indicating the existence of $-\mathrm{CH}_{2}$ group. Vibration bending at 999.13 and $763.81 \mathrm{~cm}^{-1}$ indicating the presence of $\mathrm{C}-\mathrm{O}-\mathrm{S}$ group and bending vibration at $1284.59 \mathrm{~cm}^{-1}$ shows the existence of group $\mathrm{S}=\mathrm{O}_{2}$.

Broad band at $2800-3000 \mathrm{~cm}^{-1}$ and $3100-3500 \mathrm{~cm}^{-1}$ shows vibration stretching ${ }^{10} \mathrm{C}-\mathrm{H}$ and $\mathrm{O}-\mathrm{H}^{24,41}$. The wide peak at $1134-983 \mathrm{~cm}^{-1}$ is a bending characteristic of $\mathrm{C}-\mathrm{OH}^{11}$. The peak at $1635 \mathrm{~cm}^{-1}$ indicates a bond between the polysaccharide and water ${ }^{12}$. Symmetric bending at $1300-1200 \mathrm{~cm}-1$ shows the presence of $\mathrm{S}=\mathrm{O} 2$ group and various strong bending at $1000-769 \mathrm{~cm}-1$ shows the presence of SOC group ${ }^{12}$, while bending vibration at $1256 \mathrm{~cm}^{-1}$ in sulfated guar gum and at $1259 \mathrm{~cm}^{-1}$ in Caatinga biome ${ }^{5}$. This indicates that galactomannan from palm seeds has been successfully sulfated.

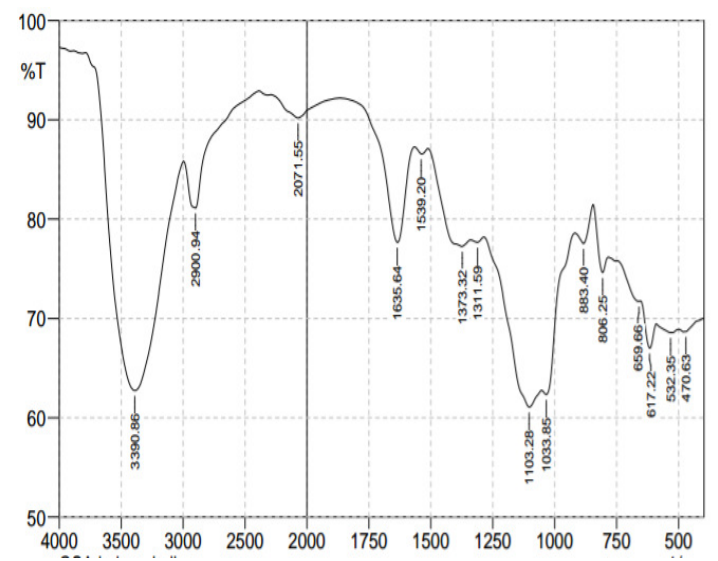

(a)

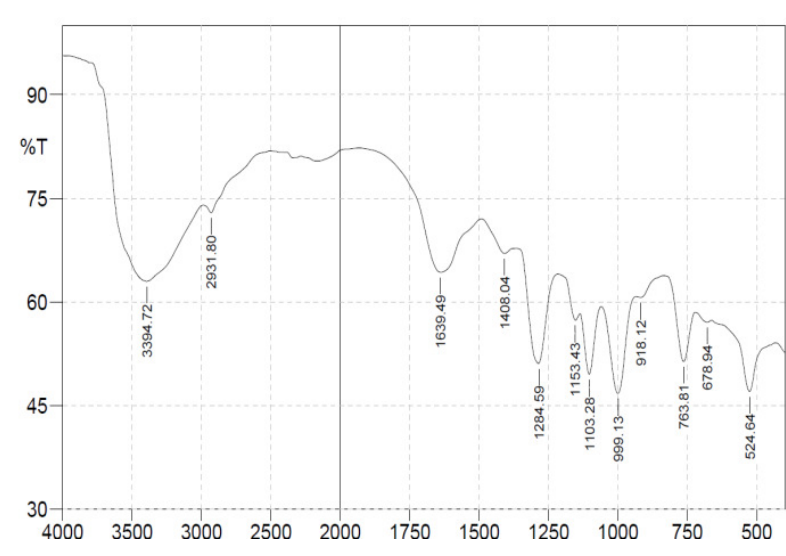

(b)

Fig.-1: FT-IR Spectrum from (a) Palm Seed Galactomannan and (b) Sulfated Galactomannan

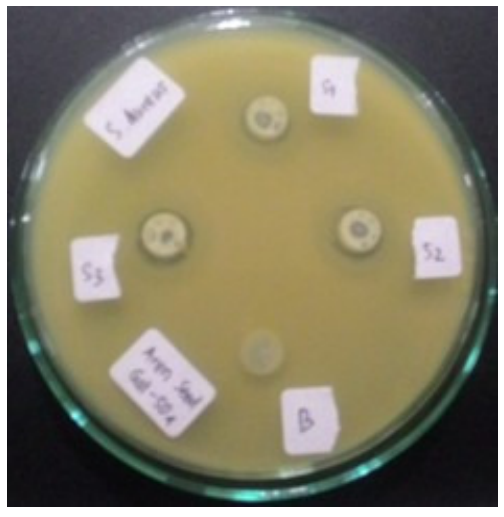

(a)

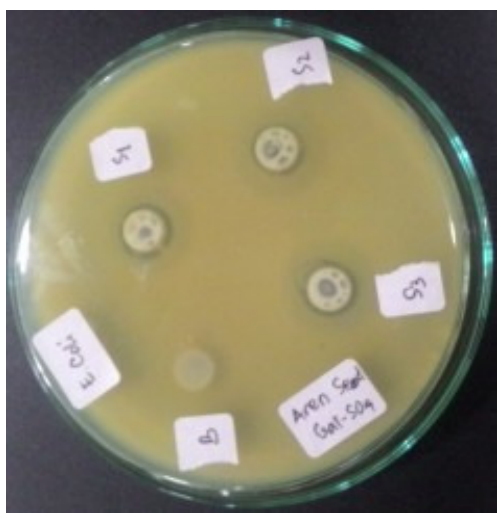

(b)

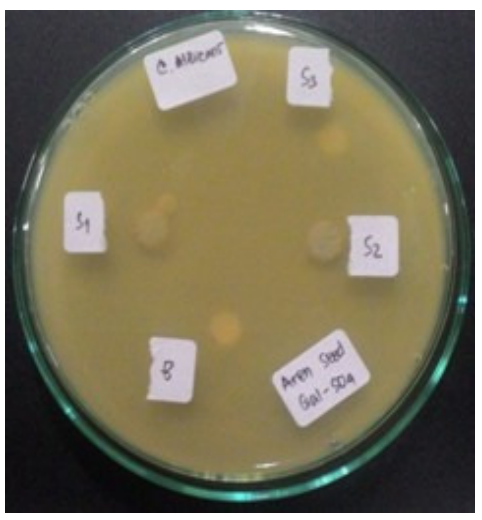

(c)

Fig.-2: Galactomannan sulfated palm seed antimicrobial activity to (a) Staphylococcus aureus, (b) Eschericia coli, and (c) Candida albicans

\section{Antimicrobial Test of Sulfated Galactomannan}

Sulfated galactomannan with concentration of $100 \mathrm{mg} / \mathrm{ml}$ has inhibitory resistance to Staphylococcus aureus ATCC 29737 at 9.50, 9.71 and $9.66 \mathrm{~mm}$ and Eschericia coli ATCC 10536 at 9.31, 9.00, $9.30 \mathrm{~mm}$ (not reduced the diameter of metal ring by $6 \mathrm{~mm}$ ) so it can be categorized as having activity antibacterial medium (medium), but did not show inhibitory activity against Candida albicans ATCC 10231 growth. Criterion of antibacterial power strength ie $5 \mathrm{~mm}$ or less inhibition zone is as the weak category, $5-10 \mathrm{~mm}$ inhibition zone is categorized as moderate, $10-20 \mathrm{~mm}$ inhibit zone is categorized as strong and inhibit zone $20 \mathrm{~mm}$ or more is categorized very strong. ${ }^{13}$ Sulfated galactomannan activity of palm seeds inhibiting the growth of Gram-positive bacteria Staphylococcus aureus is more sensitive when compared 
RASĀYAN J. Chem.

Vol. 11 | No. 1 |294 - 299 | January - March | 2018

with Gram negative bacteria Escherichia coli. This is due to differences in cell wall structure of both types of bacteria. ${ }^{14,15}$ Gram positive bacteria cell wall consists of several layers of peptidoglycan forming a thick and rigid structure and contains the substance of a cell wall called teicoic acid, while the Gram negative cell wall is composed a little peptidoglycan layers but has a thick layer of lipoprotein, Gramnegative cell wall cells are resistant to physical shocks, such as antibiotics or other antibacterial agents. In addition, difference in cell wall structure is what causes both types of bacteria to respond to Gram staining. ${ }^{15,17}$

\section{Toxicity Test Result}

Observations on testing of toxic effects were performed on each group, the toxic effects that occurred were observed compared with controls. Observation time is every 30 minutes, 60 minutes, 90 minutes, 120 minutes, 150 minutes, 180 minutes, 210 minutes, and 240 minutes. The total observation time is 4 hours periodically and continued during the first 24 hours ${ }^{18}$. In the treatment group, there were observations on the presence of toxic symptoms and testing which included stage test, catalepsy test and swing test on the control group (galactomannan of palm seed) and sulfated galactomannan of palm seed (GPS) at doses 2000 and $5000 \mathrm{mg} / \mathrm{kg} \mathrm{BW}$. Weighing is done every day for 14 days. Percentage changes in body weight per week can be seen in Table-1 below.

Table-1 showed that there is a difference between control and treatment groups. This shows that sulfated galactomannan of palm seeds has an effect on body weight of mice, but it is said toxic in case of weight loss up to $10 \%^{19}$. The results of observation of animal mortality for 14 days of test preparation can be seen in Table-2 below. Based on Table-2 it can be seen that on the 13th day the death of 2 mice occurred in GPS dose $5000 \mathrm{mg} / \mathrm{kg} \mathrm{BW}$, not one mouse died at GPS dosage $\leq 2000 \mathrm{mg} / \mathrm{kg} \mathrm{BW}$. The doses of 5000 $\mathrm{mg} / \mathrm{kg} \mathrm{BW}$ there is a significant LD50 of $5000 \mathrm{mg} / \mathrm{kg} \mathrm{BW}$ so it is included in mild toxic criteria. ${ }^{20}$

Table-1: Percentage of Weight Loss Week

\begin{tabular}{l|c|c|c|c|c}
\hline \multirow{2}{*}{ Treatment } & \multicolumn{3}{|c|}{ Body weight (g) \pm SD } & \multicolumn{2}{c}{$\%$ Change } \\
\cline { 2 - 5 } & Week 0 & Week 1 & Week 2 & Week 1 & Week 2 \\
\hline \multirow{2}{*}{ Control } & $27,38 \pm$ & $27,58 \pm$ & $27,37 \pm$ & $+0,79 \%$ & $+0,74 \%$ \\
\cline { 2 - 4 } & 1,43 & 1,37 & 1,42 & & \\
\hline \multirow{2}{*}{$\begin{array}{l}\text { GPS Dose } 2000 \mathrm{mg} / \mathrm{Kg} \\
\text { BW }\end{array}$} & $23,84 \pm$ & $23,11 \pm$ & $22,74 \pm$ & $-2,93 \%$ & $-4,65 \%$ \\
\cline { 2 - 4 } & 1,28 & 0,63 & 1,31 & & \\
\hline GPS Dose 5000 mg/Kg & $23,84 \pm$ & $23,04 \pm$ & $22,88 \pm$ & $-3,32 \%$ & $-4,04 \%$ \\
\cline { 2 - 4 } BW & 1,64 & 1,53 & 1,70 & & \\
\hline
\end{tabular}

Organs in dead mice are directly autopsied and weighed, while those still alive to the end of the observation period are autopsied and weighed. Based on Table- 2 there is a difference in the weight of the kidney organ in which the group of $5000 \mathrm{mg} / \mathrm{kg}$ body weight decreases in the kidney organ, while the liver does not lose weight in each treatment group. This shows that the effect of sulfated galactomannan of palm seeds on the weight of renal kidney organ at dose $5000 \mathrm{mg} / \mathrm{kg} \mathrm{BW}$.

This study was conducted to see the histopathology of the liver and kidneys of mice. The liver is the largest organ found in the body, the liver is composed of cells called hepatocytes. Hepatocytes are grouped epithelial cells forming interconnected plates. Hepatocytes are arranged to form liver lobules with central vein as a center. The gaps between the hepatocyte-formed plates contain the microvascular component of the liver sinusoid ${ }^{20}$.

Based on Fig.-3, histopathologic examination results were performed on the liver organ of the mice with the control group and the treatment group, to see the abnormalities of the organ microscopically performed 200 times magnification. From histopathology result of liver organ can be concluded that histopathology of liver in control group and dose treatment group $2000 \mathrm{mg} / \mathrm{kg} \mathrm{BW}$ still in normal condition that hepatocytes are arranged radial in liver lobule and not yet exist seen the occurrence of 
RASĀYAN J. Chem.

Vol. 11 | No. 1 |294 - 299 | January - March | 2018

necrosis, whereas in the treatment group dose $5000 \mathrm{mg} / \mathrm{kg} \mathrm{BW}$ it appears that this began to experience damage characterized by irregular sinusoid arrangement and vacuolization occur.

Table-2: Observation of Mice Mortality

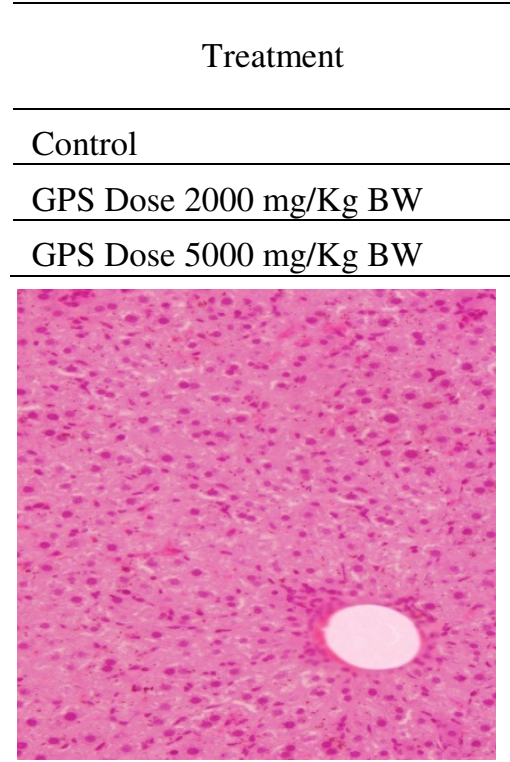

(a)

\begin{tabular}{c|c|c}
\multirow{2}{*}{$\begin{array}{c}\text { Uumber of dead } \\
\text { mice }\end{array}$} & \multicolumn{2}{|c}{ Average weight of organs } \\
\cline { 2 - 3 } & Liver & Kidney \\
\hline 0 & $5,3 \%$ & $1,3 \%$ \\
\hline 0 & $5,3 \%$ & $1,3 \%$ \\
\hline 2 & $5,0 \%$ & $1,0 \%$ \\
\hline
\end{tabular}

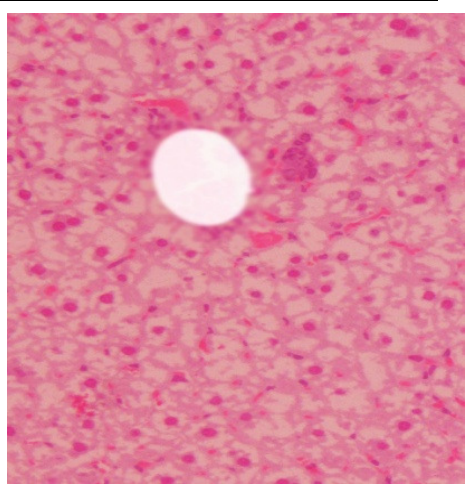

(c)

Fig.-3: Liver histopathology: (a) Control, (b) Dose $2000 \mathrm{mg} / \mathrm{kgBW}$, (c) Dose $5000 \mathrm{mg} / \mathrm{kgBW}$

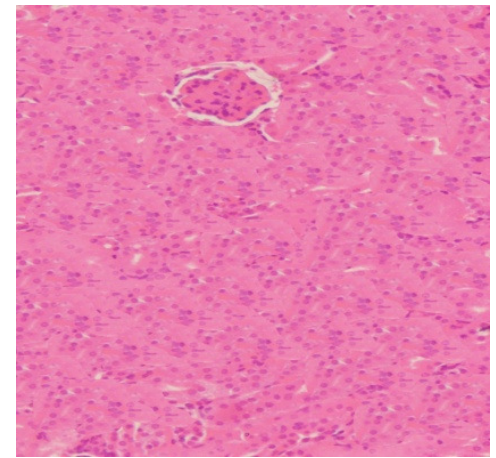

(a)

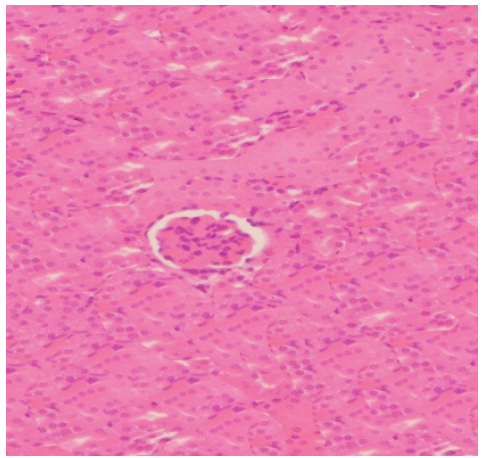

(b)

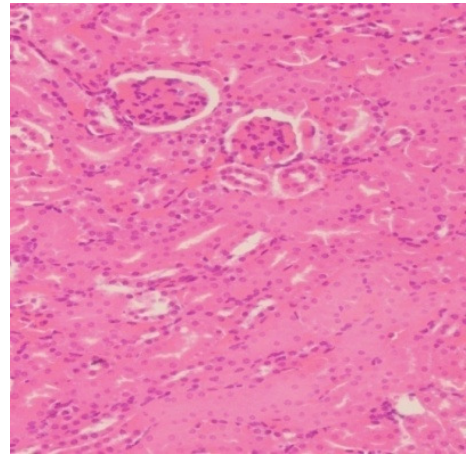

(c)

Fig.-4. Kidney histopathology: (a) Control, (b) Dose $2000 \mathrm{mg} / \mathrm{kg} \mathrm{BW,} \mathrm{(c)} \mathrm{Dose} 5000 \mathrm{mg} / \mathrm{kgBW}$

Based on Fig.-4, the histopathologic examination was performed on the renal female kidney organ with the control group and the treatment group, to see the abnormalities of the organ microscopically performed 200 times magnification. From histopathology result of renal organ can be concluded that histopathology of renal organ in control group and dosage treatment group $2000 \mathrm{mg} / \mathrm{kg}$ BW still in normal condition there is no visible occurrence of hemorrhage or necrosis, treatment dose $5000 \mathrm{mg} / \mathrm{kg}$ BW saw that this began to experience damage that is marked by the occurrence of vacuolization and hemorrhage.

\section{ACKNOWLEDGEMENT}

Best regards to the Research Institute University of Sumatera Utara which has funded university superior research scheme (TALENTA 2017).

\section{REFERENCES}

1. P. Kooiman, Carbohyd. Res., 20(2), 329(1971)

2. L.Sanchez-Gonzalez, M.Vargas, C.Gonzalez-Martinez, A.Chiralt, and M.Chafer, Food Eng. Rev., 3, 1 (2011). 
3. S.Soeda, T.Kozako, K.Iwata and H.Shimeno, Biochim Biophys Acta, 1497(1), 127(2000).

4. M.Jindal, V.Rana, V.Kumar, R.S. Singh, J.F. Kennedy, A.K. Tiwary, Carbohydrate Polymers, 92(2), 1660(2013).

5. M.M.Marques, S.M.D.Morais, A.R.D.Silva, N.D.Barroso, T.R.P.Filho, F.M.D.C.Araújo, I. G. P. Vieira, D.M.Lima and M.I.F.Guedes, Antiviral and Antioxidant Activities of Sulfated Galactomannans from Plants of Caatinga Biome, Evidence-Based Complementary and Alternative Medicine, 2015 (2015)

6. C.Mahner, M.D.Lechner and E.Nordmeier, Carbohydrate Research, 331(2), 203(2001).

7. Masfria, G.Haro, Nerdy, V.Mierza, H.S.Wahyuni, Y.M.Permata, International Journal of PharmTech Research, 9(11), 110(2016).

8. K.Sampath, K.Karthik, R.Sivahari, P.Arunkumar, Rasayan J.Chem., 10(4), 1184(2017).

9. Rosidah, M.F.Yam, A.Sadikun, M. Ahmad, G.A.Akowuah, M.Z.Asmawi, Journal of Ethnopharmacology, 123(2), 1(2009).

10. S.Yuen, C.Siu-Mei, L.P.David and M.Ching-Yung, Food Chemistry, 114(3), 1091(2009).

11. M.R.S.Prashanth, K.S.Parvathy, N.S.Susheelamma, K.V.H.Prashanth, R.N.Tharanathan, A.Cha and G.Anilkumar, Food Hydrocolloids, 20(8), 1198(2006).

12. R.M.Silverstein, G.G.Bassler, T.C.Morrill, Spectrometric Identification of Organic Compounds. John Wiley \&Sons. New York. $7^{\text {Ed }}$. p. 130-131 (2005).

13. W.W.Davis, T.R.Stout, Applied Microbiology, 22(4), 659(1971).

14. K.C.Huang, R.Mukhopadhyay, B.Wen, Z.Gitai, N.S.Wingreen. Cell shape and cell-wall organization in Gram-negative bacteria. PNAS, 105(49), 19282(2008).

15. P.Avato, R.Bucci, A.Tava, C.Vitalli, A.Rosato, Z.Bialy, M.Jurzysta. Antimicrobial Activity of Saponins from Medicago sp.: Structure-Activity Relationship. Phytotherapy Research, 20(6), 454(2006).

16. C.T.Handoko, A.Huda, M.D.Bustan, B.Yudono, F.Gulo. Green Synthesis of Silver Nanoparticle and Its Antibacterial Activity. Rasayan J.Chem., 10(4), 1137(2017).

17. G.More, S.Bootwala, S.Patade, D.Raut, K.Aruna. Synthesis, Spectroscopic, And Biological Activity Studies Of the Ni (II) Complexes Of Tridentate Schiff Bases. Rasayan J.Chem., 10(4), 1511(2017).

18. OECD. Organization for Economic Cooperation and Development. Guidelines for the Testing of Chemicals, 407(1), 1(2008).

19. OECD. Acute Oral Toxicity - Acute Toxic Class Method. OECD Guidelines for Testing Chemicals, 423(1), 1(2001).

20. L.C.Junquera, J.Carneiro, Basic Histology, Text and Atlas, 11th ed, McGraw, Hill Companies. p.130139 (2009).

[RJC-2039/2017] 